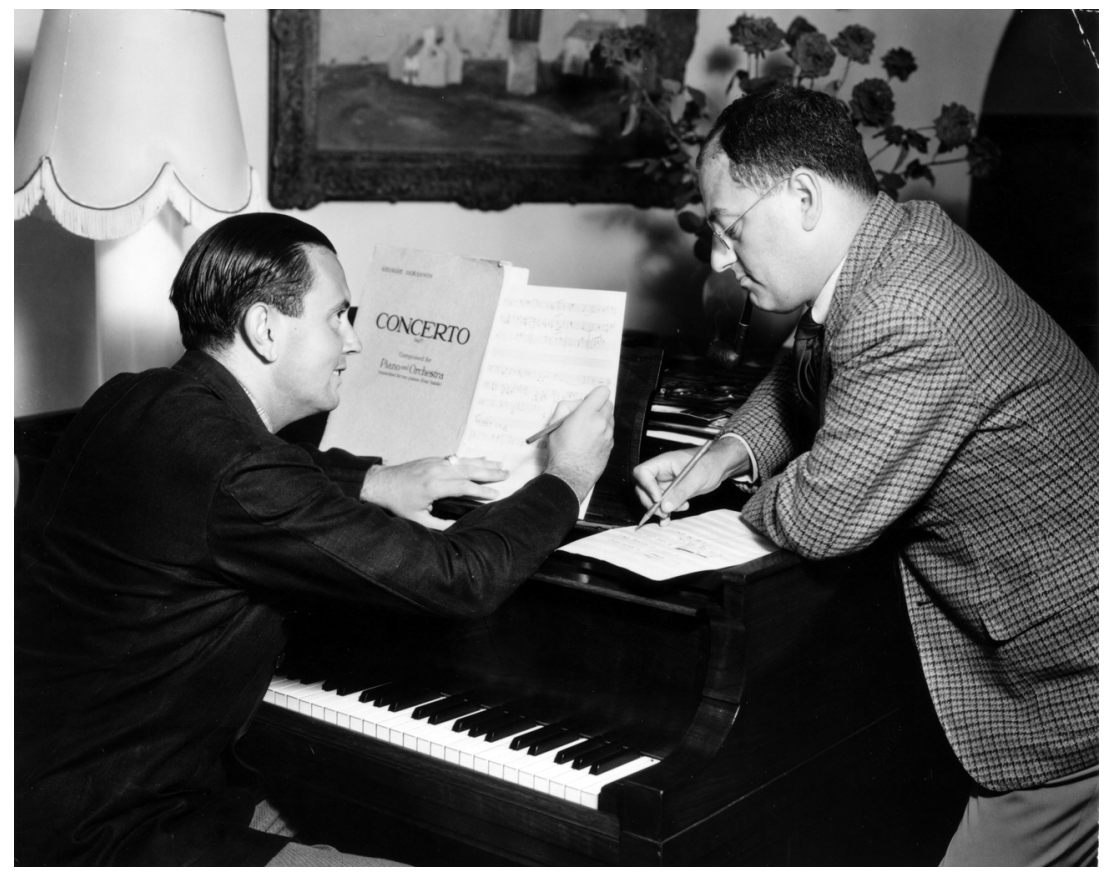

Figure 1. Photograph courtesy of the Ira and Leonore Gershwin Trusts 


\section{One Person, One Music: Reconsidering the Duke-Dukelsky Musical Style}

In this photograph from 1937 (see fig. 1), Vernon Duke (left) and Ira Gershwin (right) huddle at the piano, presumably collaborating on a song for a Hollywood film musical. Yet beside Duke's manuscript on the piano rack sits the score to a concerto and not another popular song. ${ }^{1}$ This photo visually encapsulates the dual identity that shaped the composer's entire career. Vladimir Dukelsky, born in 1903, was classically trained in Kiev under Reinhold Glière. His output includes three symphonies, various concertos, an opera, choral works, ballet scores, chamber music, song cycles, and piano pieces. "Vernon Duke" is the pseudonym he attached to his popular songs, Broadway scores, and lighter "jazz"-style compo-sitions. Until his death in 1969, both "Duke" and "Dukelsky" were suc-cessful composers in their own independent spheres of activity.

Duke himself promotes this compositional duality in his autobiogra-phy, Passport to Paris. ${ }^{2}$ He immediately draws his readers' attention to the DukeDukelsky issue, filling the first two pages with musings on the subject. As he sees it, not only does the name designate the division of his works into "highand low-brow genre[s]," but he also insists that in his compositions, unlike in the compositions of some of his contempo-raries, the two styles do not mix:

Aaron Ziegel is completing a Ph.D. in musicology at the University of Illinois, Urbana-Champaign. He is currently writing his dissertation titled, "Making America Operatic: Six Composers' Attempts at an American National Opera," which examines works from the 1910s. A summa cum laude graduate in piano performance from the University of Cincinnati, he was the 2007-8 recipient of the AMS Midwest Chapter A-R Editions Award for a paper on Schumann's early, unfinished Symphony in G Minor. 
Gershwin always remained Gershwin whether he wrote Porgy or "I Got Rhythm"; Weill was easily recognizable as Weill whether he tackled Mahagonny or One Touch of Venus; and even Lennie Bernstein is his ingratiating self whether he tears into Jeremiah or On the Town; but Dukelsky in no way resembles Duke.

There isn't a note of jazz in my serious music, and there are no symphonic overtones to my musical-comedy output. ${ }^{3}$

As quoted in his obituary, he was even more explicit about the divided nature of both his compositions and his personality: "I always feel the duality in myself. . . My light music is decidedly extrovert, my serious music is introvert. There's my Carnegie Hall self and my Lindy's self, my Russian heritage and my American influence. Can I help it if two people happen to be in my body?"4 In response to an interviewer in Chicago, he claimed, "The two idioms in which I write are as different as work and play. Serious music is hard work; jazz is . . just recreation for which I happen to get paid." 5

Elliott Carter, for one, was convinced by this division. Writing in 1938, he explained that "Dukelsky is a dual personality in music. His stan-dardized popular songs (the 'active' listener will remember them) writ-ten under the less frightening name of Vernon Duke, have absolutely no connection with his original and imaginative serious music in either style or content." " $\mathrm{Later}$ writers have generally accepted this segregation of Duke's two musics as well. Nowhere in the published literature are the composer's classical works and his popular songs considered side by side. ${ }^{7}$ Alec Wilder takes a typical position:

Vernon Duke was only one half of his musical self; the other half was Vladimir Dukelsky, a composer of concert works. Unfortunately for all of us, the concert, so-called "serious" side of this man's talent never, so far as I know, attempted to employ his popular side in a "third stream" fashion. . . . No, Mr. Duke-Dukelsky kept his musical selves compartmentalized. And it is only with the Duke half that I am here concerned. ${ }^{8}$

Because writers tend to isolate Duke's two composing halves, they have had little success at characterizing his compositional style. Aaron Cop-land, for example, writing in 1931 and thinking only of Dukelsky's concert works, does not conceal his struggle to come up with this assessment:

Dukelsky has the making of a real style, obviously lyrical, and the difficulty consists in defining it. Certain aspects of his music relate him to Prokofiev: a fresh melodic gift, an aristocratic charm and grace, and an easy flair. The exact quality of the style, however, is not so easily grasped, inasmuch as it is less apparent, and the music in general possibly has fewer mannerisms than Prokofiev's. ${ }^{9}$ 
Still, examining Duke's work, one finds patterns of stylistic consistency that unite his two compositional personalities. Those patterns undercut Duke's professed dual identity as a composer. His self-construction as a composer with competing or alternating musical personas appears to be an artifice of creative protection, one might say, born out of the struggle to win success in both the popular and classical arenas.

The composer relates an amusing anecdote to suggest that his stylistic breadth was determined while he was still in the womb. Four months prior to his birth, his mother was startled by a ferryboat's siren. She grabbed her left ear to block the noise and came away with a "fleeting superstition that the left ear of her unborn child would be marked." Sure enough, Duke was born with a cleft earlobe on his left side. The composer jokes that "possibly my left ear has never heard what the right ear heareth, and there you have the whole mystery of Duke and Dukelsky in an earshell. The question is, which of the two ears is at-tuned to Jazz?"10

Duke enjoyed a wide spectrum of musical outlets from an early age. As a teen, while studying composition with Glière, Duke would also "rattl[e] off polkas, tangos, and the increasingly popular American two-steps" on the piano at parties. Having fled the Russian Revolution because of his aristocratic family lines, the Dukelsky family arrived in Constantinople in 1920. There Duke played in a piano trio at a restaurant, accompanied silent films, and composed piano pieces and song cycles. He had his first encounters with American popular songs, including some of Irving Berlin's early hits, but he was more impressed by Gershwin's "Swanee" and tried to compose some admittedly unsuccessful popular songs of his own. Concurrently, he prepared his first ballet score, which he de-scribed as "minor-league Scheherazade-cum-Glazunov," even through the premiere "was fairly well received." 11

Once the Dukelsky family settled in New York City in 1921, his musical activities continued across a wide range of styles: composing for vaude-ville performers and accompanying a burlesque called Jazz Babies while serving as vocal coach and accompanist for operatic voice students and struggling to find time for classical composition. Tin Pan Alley publishers rejected the first batch of popular songs he offered, which at this stage would have appeared under the pseudonym of Alan Lane or Ivan Ivin. In the classical music sphere, he composed a concert overture premiered at Carnegie Hall. New friendships opened doors for Duke in both direc-tions: George Gershwin provided Duke with a valuable entrée into the popular song business, while the singers Nina Koshetz and Eva Gauthier broadened his range of classical contacts. Duke writes, "Without real-izing it, I was already leading the dual musical existence which became 
my trademark in the thirties." He sums up this period of his life as "my daily pursuits of Euterpe and greenbacks." 12

This constant struggle to establish himself as a composer reached a crisis point one night when Duke was playing piano along with "syn-thetic gypsies [performing] in a pseudo-Russian midtown night spot." Who should come in to the restaurant but Karol Szymanowski, along with Alfredo Casella, Emerson Whithorne, and Lazar Saminsky, among others. Duke writes,

Words cannot describe my despair and mortification. Here were my senior contemporaries, proudly practicing their craft—nay, my craft! - and here was I, a young fellow composer, about to prostitute myself publicly. . . . [T]he hellish humiliation of my lower-than-lowbrow jobs was not justifiable in view of the pittances I received for them. . . I would forever renounce the métier of an eatery piano player. $^{13}$

Attempting to strengthen his position as a classical composer, Duke traveled to Paris in 1924, like so many other American composers of the time. This move was encouraged in large part by the pianist Artur Ru-binstein, who had enjoyed some of Duke's early piano pieces and asked the composer for a single-movement concerto. ${ }^{14}$ In order to fund the trip, Duke sought Gershwin's help. Gershwin, who was overworked at the time, employed Duke (through Harms Music) as a ghostwriter and piano arranger. His tasks included preparing the sheet music version of "Somebody Loves Me" and arranging the piano solo version of Rhapsody in Blue. ${ }^{15}$ Once again, Duke's concurrent work at both the popular and classical fronts advanced his career.

In Paris he came in contact with Stravinsky and the members of Les Six, but most important, he became an associate of Diaghilev's Ballets Russes. For Diaghilev, Duke composed the ballet score Zéphyr et Flore. This work brought Duke to international prominence with successful runs in Paris, Monte Carlo, and London. ${ }^{16}$ Having followed the ballet to London, Duke began composing popular songs for interpolation into operetta productions. He explains that "I started a career of 'doctor-ing' ailing Viennese operettas and 'jazzing 'em up' to suit the changing tastes." His success with these tunes led to commissions for full-length musical comedies, including one called Yellow Mask, which opened in 1928. While working on this score, Duke also began his First Symphony. Serge Koussevitzky premiered the symphony with the Boston Symphony while Duke was still in Europe. Eventually becoming homesick for his family, all of whom had remained in New York, Duke decided to return to the States in 1929, "with the firm intention of giving America a second chance to discover me." 17 The work pattern that emerged, with simulta-neous efforts on both popular and classical projects, continued to define his life as a composer throughout his entire career. 
The pseudonym "Vernon Duke" was first attached to his song interpolations for London musicals. The need for a pseudonym was in fact a contractual necessity, and once again he turned to Gershwin for help and advice. Duke tells the story best:

Although my contract with Koussevitzky stipulated an exclusive lifetime partnership, I was permitted to prostitute my muse and publish such unworthy outpourings elsewhere, on condition that I find a suitable nom de plume. On my discussing this with Gershwin, he suggested that the family name was easily enough truncated to "Duke," but the Christian name presented some difficulty. There was nothing resembling "Vladimir" in English, and all the Anglo-Saxon names beginning with "V" already had Russian counterparts-ex-cept Vernon. The name "Vernon Duke" had a somewhat purple-fiction ring to it, but since musical comedy was not an especially elevated form of art, that did not seem to constitute an obstacle. Thus my first published song, "Try a Little Kiss," was signed with the Gershwin-invented handle, which stuck through all these years until it became my official name and relegated the Slavic "Dukelsky" to the status of a pseudonym. ${ }^{18}$

Duke's comments echo the disparaging attitude toward popular medi-ums that he continued to struggle with as a composer at this early stage in his career. He still saw himself as a classically trained composer of art music who just happened to write popular songs on the side. As his ca-reer progressed, however, he learned to accept both fields as a spectrum of legitimate compositional pursuits, despite resistance from the public, music publishers, and critics to his wide-ranging activities.

By the early 1940s Duke's mature compositional style was firmly established. He had already penned his two most enduring standards, "April in Paris" (1932) and "Autumn in New York" (1934). His first two symphonies had been performed by orchestras throughout the United States. He was at the height of his compositional powers and was look-ing to make his lasting mark as a composer. Duke himself recognized the significance of these years and viewed the early forties as an important career threshold:

Still described as a "young" composer (the adjective "promising" having vanished a few years earlier), I had made a better than fair mark in both fields; what remained was the decisive "strike," or rather two strikes, simultaneously, if possible, that would bring me eminence and financial security by the time I reached forty. ${ }^{19}$

Thus, these years provide an apt timeframe for a study of his musical 
style. Table 1 lists the compositions from these crucial years examined here. Two of the popular songs come from Cabin in the Sky, Duke's most successful musical-perhaps this is the Broadway "strike" he was anticipating. ${ }^{20}$ Two solo piano pieces, Variation on "Swanee River" and "New York Nocturne," fit into a stylistic middle-ground, combining a Broadway "jazz" aesthetic with concert-quality piano writing, similar in tone to the Gershwin Preludes. The Victorian Songs, Three Caprices, and "Barrel-Organ Barcarolle" are in his classical concert style, explicitly designated by the attribution to Vladimir Dukelsky in the published score. ${ }^{21}$ The Cello Concerto, a great success under Serge Koussevitzky and Gregor Piatigorsky, could be the hoped-for classical "strike." Among these works one finds traits that unite the classical Dukelsky with the Broadway Duke.

Twentieth-century composers who, like Duke, chose not to abandon tonality shared a range of common devices in an effort to broaden their tonal palette. Such devices are part and parcel of what Duke's contem-porary, the theorist and composer Rudolph Reti, termed "expanded tonality." Reti defined this as "a state where one basic tonality still pre-vails"; it is a harmonic system "still firmly based on the classical cadence . . . even though the detail of its texture is laden with series of passing chords, harmonic deviations and free key relationships." 22 This descrip-

Table 1. List of compositions selected for comparison

\begin{tabular}{|c|c|c|c|}
\hline Year & Title & Attribution & Publisher \\
\hline \multirow[t]{2}{*}{1939} & Variation on "Swanee River" for Piano & Vernon Duke & Robbins Music \\
\hline & "New York Nocturne" for Piano & Vernon Duke & Robbins Music \\
\hline \multirow[t]{3}{*}{1940} & "Barrel-Organ Barcarolle" for Piano & Vladimir Dukelsky & Sprague-Coleman \\
\hline & "Cabin in the Sky" from Cabin in the Sky & Vernon Duke & Miller Music \\
\hline & $\begin{array}{l}\text { "Honey in the Honeycomb" } \\
\text { from Cabin in the Sky }\end{array}$ & Vernon Duke & Leo Feist \\
\hline \multirow[t]{6}{*}{1942} & $\begin{array}{l}\text { "Tondelayo" from White Cargo } \\
\text { (film musical) }\end{array}$ & Vernon Duke & Leo Feist \\
\hline & $\begin{array}{l}\text { Five Victorian Songs for Voice and Piano } \\
\text { 1. Remember or Forget }\end{array}$ & Vladimir Dukelsky & Sprague-Coleman \\
\hline & 2. O Spirit of the Summertime & & \\
\hline & 3. No and Yes & & \\
\hline & 4. The Night Has a Thousand Eyes & & \\
\hline & 5. The Ladies of St. James & & \\
\hline \multirow[t]{6}{*}{1944} & "The Love I Long For" from & Vernon Duke & Paramount Music \\
\hline & Sadie Thompson & & \\
\hline & Three Caprices for Piano & Vladimir Dukelsky & Carl Fischer \\
\hline & 1. Molto deciso-Allegretto comodo & & \\
\hline & 2. Quasi Notturno & & \\
\hline & 3. Tempo di Valse & & \\
\hline \multirow[t]{4}{*}{1946} & Concerto for Cello and Orchestra & Vladimir Dukelsky & Carl Fischer \\
\hline & 1. Maestoso & & \\
\hline & 2. Adagietto & & \\
\hline & 3. Allegro brioso & & \\
\hline
\end{tabular}


tion matches both Duke and Dukelsky's harmonic methods in these pieces. Another of the his contemporaries, the American composer Elie Siegmeister, went so far as to suggest that "expanded tonality forms one of the basic lines of development of twentieth-century music." ${ }^{23}$ Thus, in these pieces Duke is participating in what was then recognized as the modernist mainstream.

Copland's comparison of Dukelsky to Prokofiev is instructive. Like that other Russian composer, Dukelsky is essentially tertial in his chord structures and frequently establishes key areas through the most con-ventional of means, the authentic cadence. But he also applies simple sequence and impressionist "planing," whether developing his mate-rial, approaching a new harmonic area, or reaching a cadential chord via a mere rising or falling of all (or most) voices, making the point of arrival seem not only plausible but inevitable. Consider the main theme of Dukelsky's second Caprice for piano, which begins on E-flat major but creeps upwards a half step at a time, first to E major and then F major (ex. 1) before reversing the process and winding its way back down to E flat. One sees similarly simple chromatic rising in the Duke song "Cabin in the Sky" (ex. 2). Downward chromatic falling also characterizes both Dukelsky and Duke, respectively, as seen in examples 3 and 4. Whole-step sliding frequently appears as well, shown both falling and rising in examples 5 (Duke) and 6 (Dukelsky). Marion Bauer, in her 1933 study of modern music, aptly observes that such parallel motion "has been copied by practically all the composers of this century." 24

Coloristic chord successions of either tritone-related chords or so-called chromatic mediants also pervade Duke/Dukelsky's works. Consider the lovely opening phrase of the third Caprice (ex. 7), with its opening motion from the tonic E minor to B-flat minor and ending on a G-sharp minor

Example 1. Dukelsky: Caprice no. 2, mm. 9-14

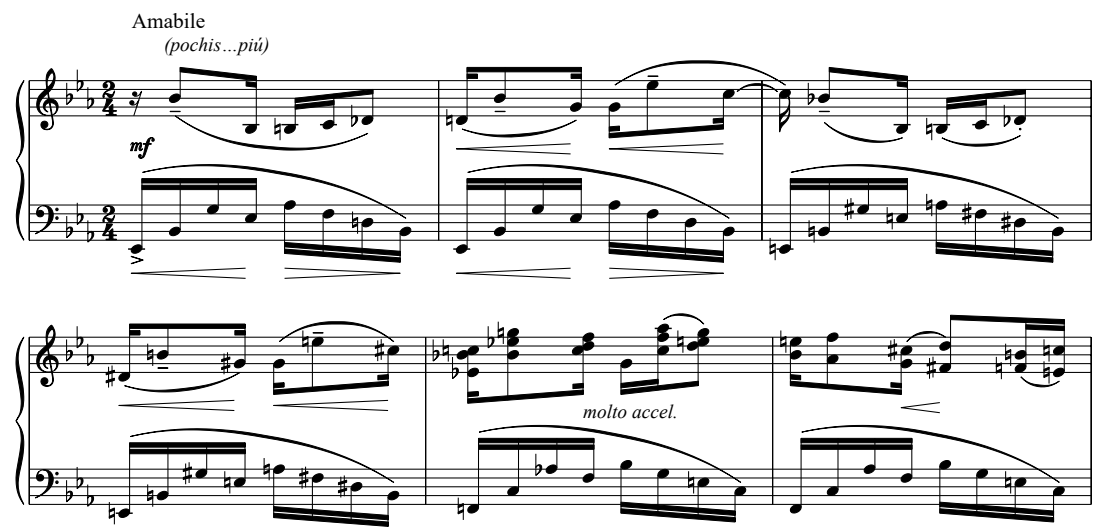


Example 2. Duke: "Cabin in the Sky," mm. 14-16

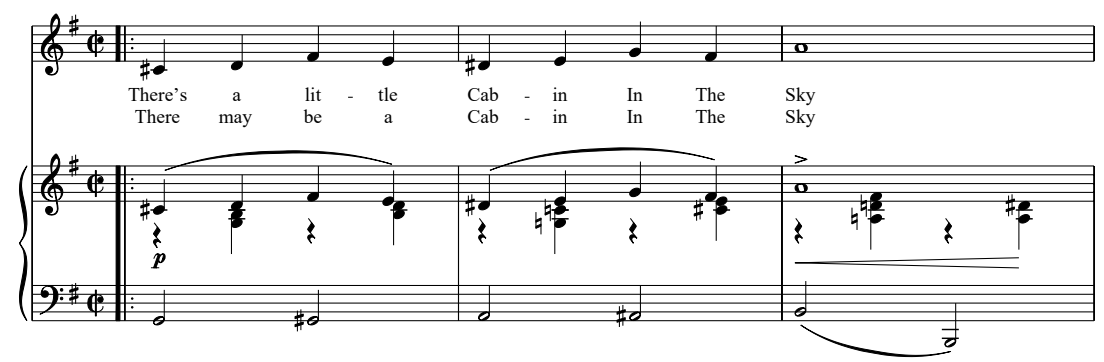

Example 3. Dukelsky: Victorian Songs, “The Night Has a Thousand Eyes,” mm. 7-9

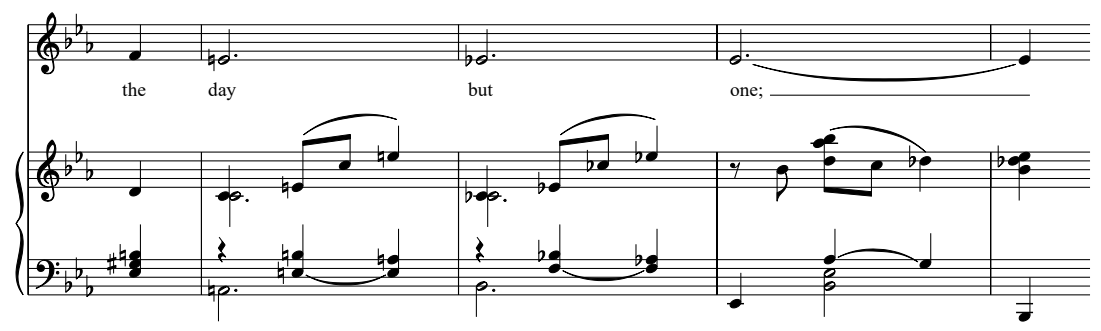

Example 4. Duke: "Honey in the Honeycomb," mm. 25-27

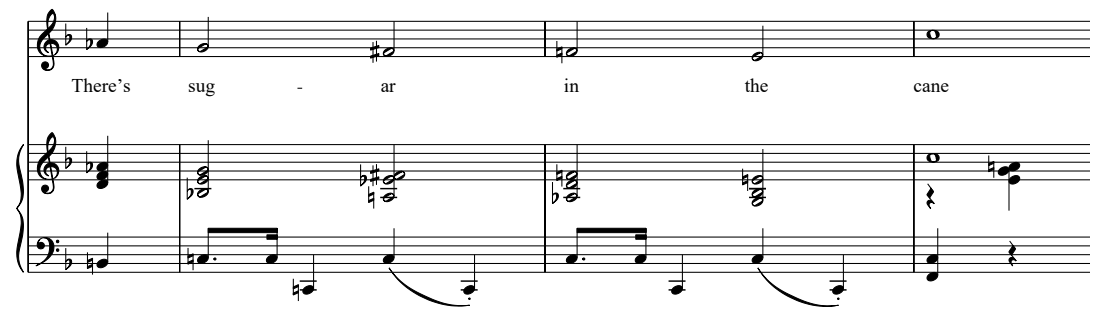

chord. Similar coloristic successions appear in the popular songs-see "The Love I Long For," with its succession of G minor and E-flat minor (extended) chords (ex. 8). ${ }^{25}$ In the "Barrel-Organ Barcarole," an encore-like character piece, Dukelsky combines chromatic mediants with stepwise sequence (ex. 9).

Beyond tertial harmony, mainstream modernists of the time often turned to quartal or quintal harmonies for a richer harmonic flavor. ${ }^{26}$ Consider Duke's accented quintal chords in the later piece "My Grocer's Dog" (from the Parisian Suite, published 1956, ex. 10). ${ }^{27}$ Or the similar chords in Dukelsky's "Remember or Forget" (ex. 11). Quartal chords appear in both the piano piece "New York Nocturne" and the popular song "Cabin in the Sky" (ex. 12 and 13). ${ }^{28}$ 
Example 5. Dukelsky: Victorian Songs, "No and Yes," mm. 15-17
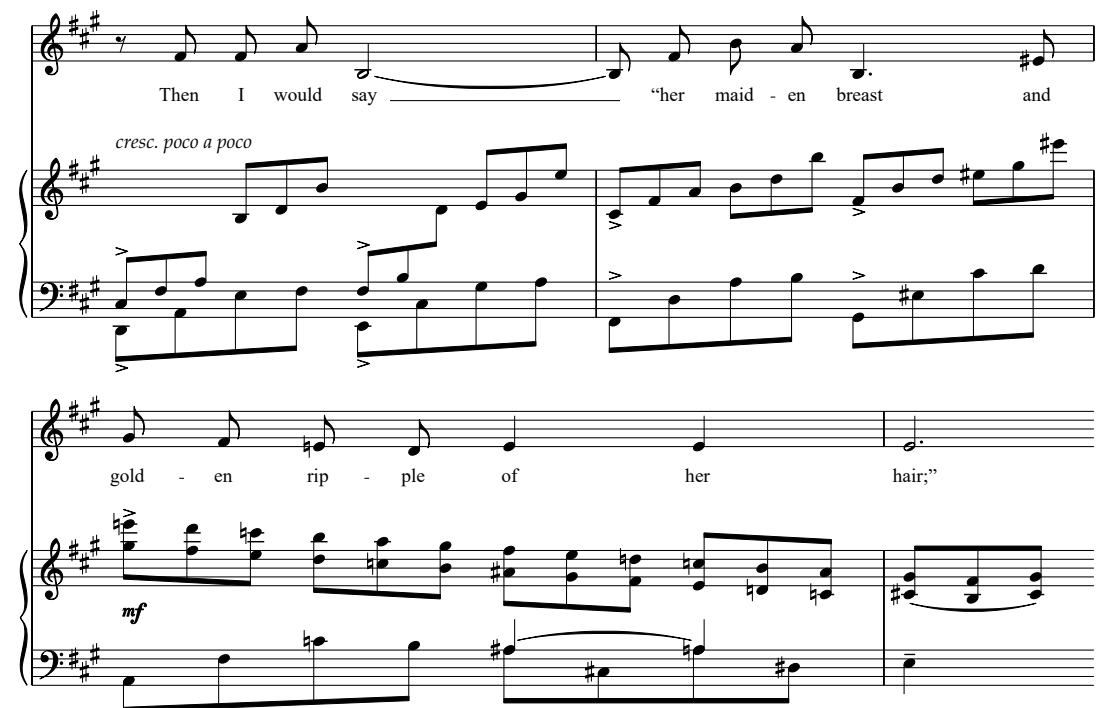

Example 6. Duke: "Tondelayo," mm. 9-12

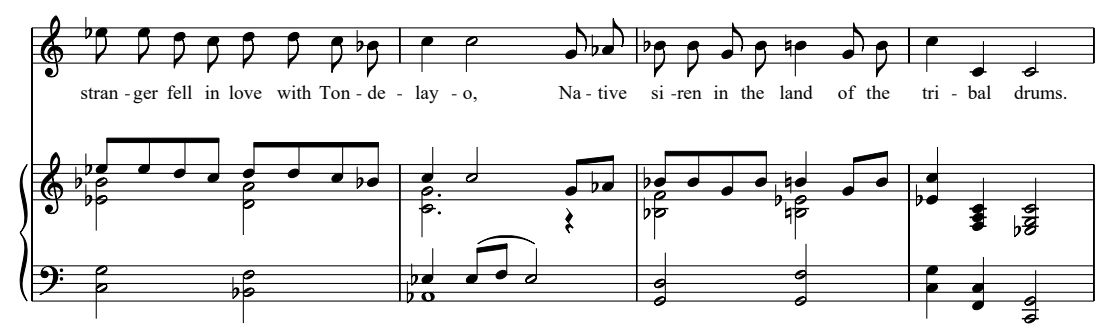

Example 7. Dukelsky: Caprice no. 3, mm. 1-8

Tempo di Valse (Moderato non troppo)

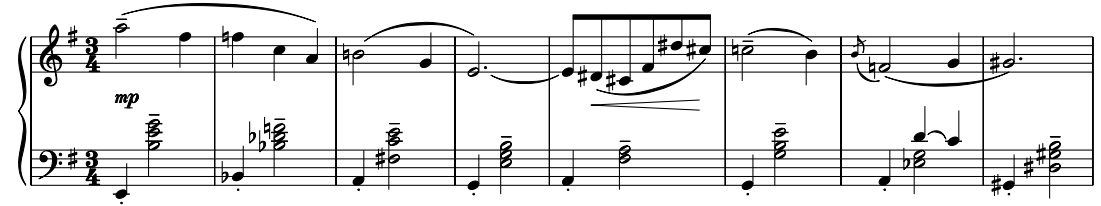

Example 8. Duke: “The Love I Long For," mm. 7-10

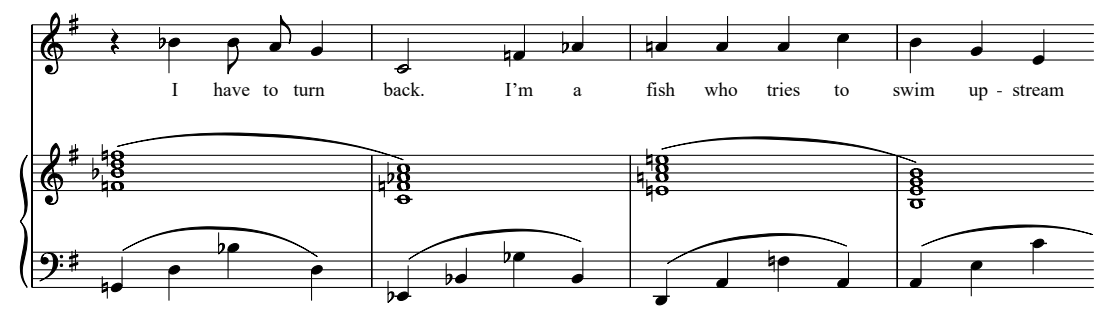


Example 9. Dukelsky, "Barrel-Organ Barcarolle,” mm. 75-78

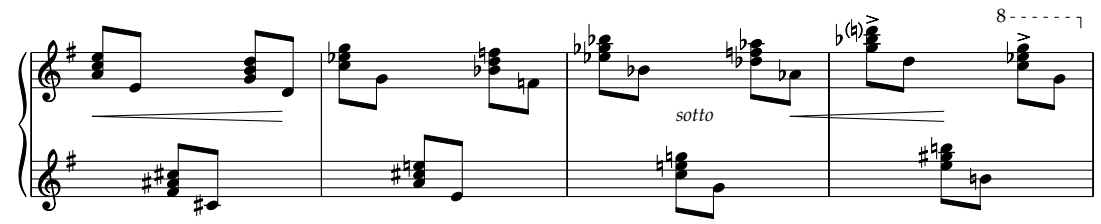

Example 10. Duke: Parisian Suite, "My Grocer's Dog,” mm. 1-4

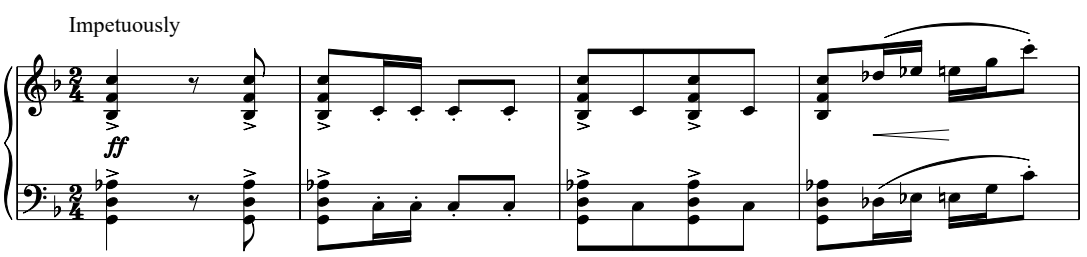

Example 11. Dukelsky: Victorian Songs, "Remember or Forget," mm. 13-17

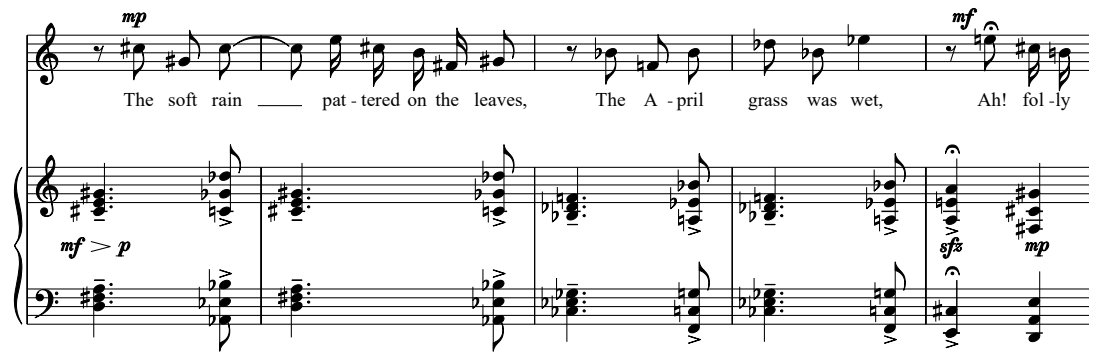

Example 12. Duke: “New York Nocturne,” mm. 94-97

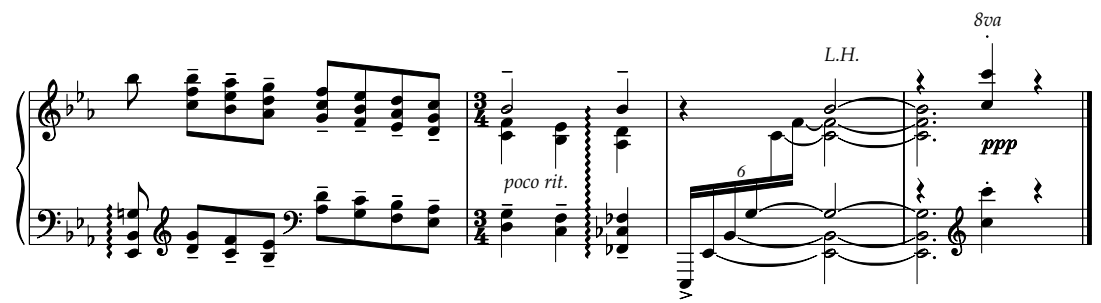

Duke's consistent approach to melodic construction in both his clas-sical compositions and his popular songs is another stylistically distinc-tive trait. Wide leaps, disjunct contours, and chromatic meandering are the common features of Duke's melodies. While this is, of course, not uncharacteristic of art songs from the period, the frequent occurrence of these traits in his popular song melodies is noteworthy. Given a melody alone, the tonic can often be unidentifiable, since Duke generally avoids 
Example 13. Duke: "Cabin in the Sky," mm. 36-37

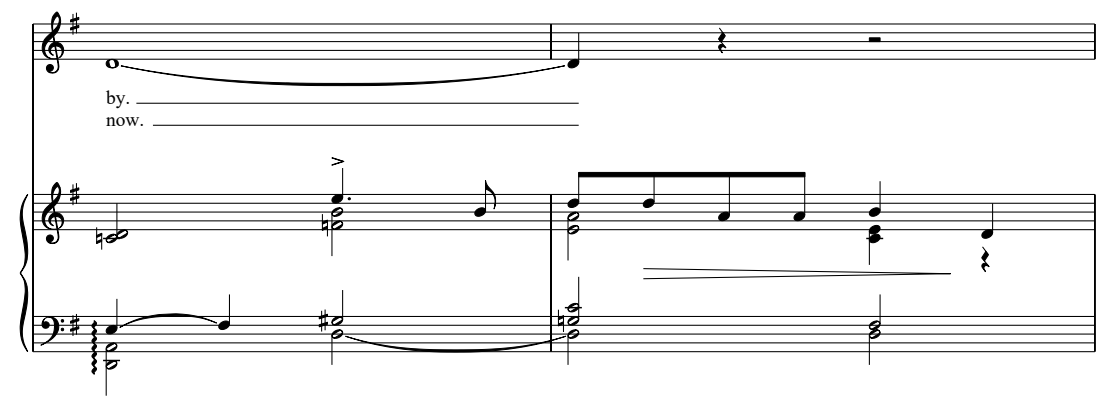

outlining the triad and prefers to begin his melodies on upward exten-sions of the harmony. Only with the support of the bass and chords does a tonal center become apparent. Although unrestricted by the limitations of singability, the melodies in Duke's piano pieces likewise display similar characteristics. Examples of Duke's characteristic melodic style appear below: from an art song (ex. 14a), a popular song (ex. 14b), and a piano piece (ex. 14c). When removed from their harmonic context, the stylistic similarities are all the more evident.

Because of Duke's idiosyncratic and complex melodic style, his melo-dies are frequently described as difficult; singers find his songs to be more demanding than the average Tin Pan Alley tune. Stephen Holden, for example, notes that "Duke introduced a refined impressionism into popular song that was as adventurous as anything composed by his more renowned songwriting peers." 29 In his theory textbook, Siegmeister of-fers a list of five "traits ... that are common to many different modern styles." Perhaps not surprisingly, three of the five- - "extreme range,"

Example 14. The Duke-Dukelsky melodic style

14a. Dukelsky: Victorian Songs, "The Night Has a Thousand Eyes," mm. 3-9

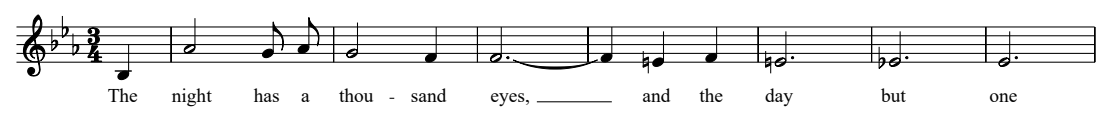

14b. Duke: "Cabin in the Sky," mm. 14-17

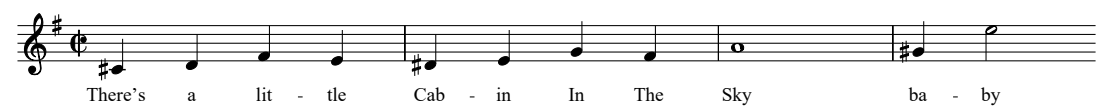

14c. Dukelsky: Caprice no. 1, mm. 14-17

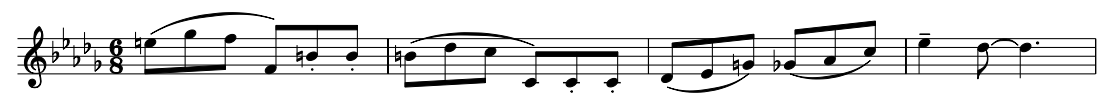


"unusual intervals and difficult leaps," and "free tonal movement"characterize Duke's melodic style. ${ }^{30}$ We might reasonably expect these traits to appear in Dukelsky's classical output; their consistent presence in Duke's popular songs is rather remarkable. ${ }^{31} \mathrm{I}$ am not suggesting that Duke's melodies for an art song or a popular song are interchangeable, but I would argue that an undeniable affinity arises through Duke's consistent use of similar techniques. There is perhaps more of Dukelsky in Duke's popular songs than even the composer himself could admit. As the array of examples here illustrate, decidedly "Euterpean" devices appear regularly throughout his "greenback-earning" popular songs.

Marion Bauer described the goals of "modern" composition "as an attempt to escape the obvious, to avoid time-worn combinations, to elide the unnecessary, to allow the mind to supply implied detail and to break down established boundaries not in a spirit of revolt but of exploration." ${ }^{32}$ Duke brought a similar "spirit of exploration" to popu-lar songwriting as Dukelsky did to his classical pieces. Duke avoided it only in one area of his popular songwriting style: form. Alec Wilder, for one, seems almost disappointed that "a schooled composer who has written a body of complex concert music should have been the man least inclined to experiment in popular music forms." 33 One can only speculate on the composer's intentions, but common sense suggests that, given how Duke stretches the boundaries of popular songwriting with a classically hued harmonic and melodic style, a standard formal structure needed to remain intact in order to help preserve a popular song's generic identity. Standardized form serves as the foundation upon which Duke could situate his melodic and harmonic exploration. (Indeed, each of the popular songs considered in this article begins with a verse section followed by a standard thirty-two-bar chorus.) At the conclusion of his Schenkerian-based analysis of the American popular ballad repertoire, Allen Forte asks, "does the study of American popular song fill a gap in the history of tonality?" 34 Duke's songs would seem to answer this question in the affirmative, for in them modern classical tonal procedures arguably find a new avenue for expression.

If one piece neatly encapsulates the stylistic convergence of Duke-Dukel-sky, it may be his (Duke's) Variation on "Swanee River" (Stephen Fos-ter's “Old Folks at Home"). The variation comes from a multi-composer collaborative set: the publisher Jack Robbins commissioned twenty-nine arrangers, composers, and pianists to each contribute a "modern piano interpretation" of the familiar tune. ${ }^{35}$ The list of contributors includes Art Tatum, Harry Warren, Johnny Green, Victor Young, Ferde Grofé, and Wil-liam Grant Still, among others. ${ }^{36}$ The purpose of such sets was to allow each arranger to demonstrate his own personal musical style at its best. Here, Duke immediately opens with right-hand quartal arpeggiations that will recur throughout the piece (ex. 15, mm. 17-20, provides the best 
example from further into the piece.) He then presents the tune, elongating the rhythms of the melody to allow ample space for harmonic variation. Although the arrangement is ostensibly in $\mathrm{F}$ major, the melody begins unexpectedly on the chromatic mediant of D major, only touching the tonic chord of $\mathrm{F}$ once in the first eight measures. Moreover, each chord is approached by a chromatic appogiatura chord before settling onto the "real" harmonies (which are shown in ex. 16). The song's bridge begins in the other chromatic mediant key, A major, neatly mirroring the open-ing. Each time the main melodic strain returns, it is harmonized with the same "wrong" D-major chord, only attaining a strong F-major closure at the final cadence, suffused with more quartal harmony.

I have saved the Cello Concerto for last because its finale more than any other example seems to belie the composer's claim that "Dukelsky in no way resembles Duke." Once again, all of Duke's cross-genre sty-listic traits make a characteristic appearance. ${ }^{37}$ Note in example 17a how Dukelsky can treat the E flat in the sixth measure of the example in two ways: at the surface level it could be read as a "blue note"-but then what is it doing in a jazz-free classical concerto by Dukelsky? Alternately, he sometimes harmonizes this pitch with the flat submediant (a chromatic mediant). When this melody reappears later in the movement carried by the full orchestra, quartal chords appear (ex. 17b). Perhaps most re-markable is the movement's simple secondary theme (ex. 17c), which, given its melodic and harmonic style, seems like a tune crying out to become a ballad in a romantic comedy. Only lyrics are missing. Here the co-mingling of Duke and Dukelsky seems complete, with little evident distinction between popular and classical styles.

It is no accident that my discussion treats only this one large-scale classical composition. Duke was most at home when composing in the smaller genres, especially character pieces and song cycles, despite the relative regularity with which he turned to larger forms (three sympho-nies, a single concerto for violin and cello each, and several works for piano and orchestra). His sophisticated melodic style does not lend itself

Example 15. Duke's reinterpretation of "Swanee River," mm. 17-20 (right hand)

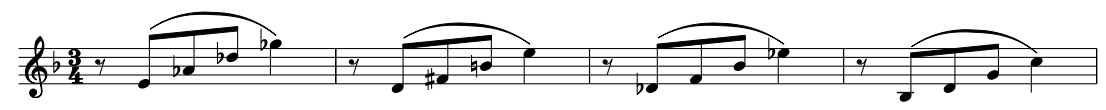

Example 16. Duke's reinterpretation of "Swanee River," mm. 5-12 (melody and supporting harmonies)

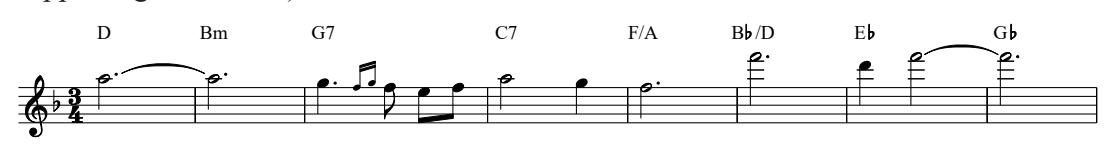


Example 17. Dukelsky: Cello Concerto excerpts

17a. Finale primary theme, rehearsal 42
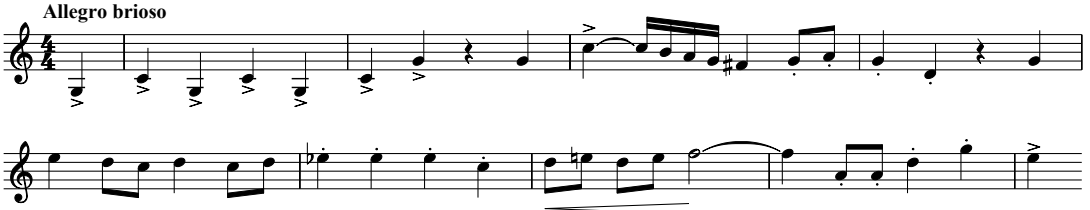

17b. Finale primary theme, orchestral reduction only, rehearsal 62
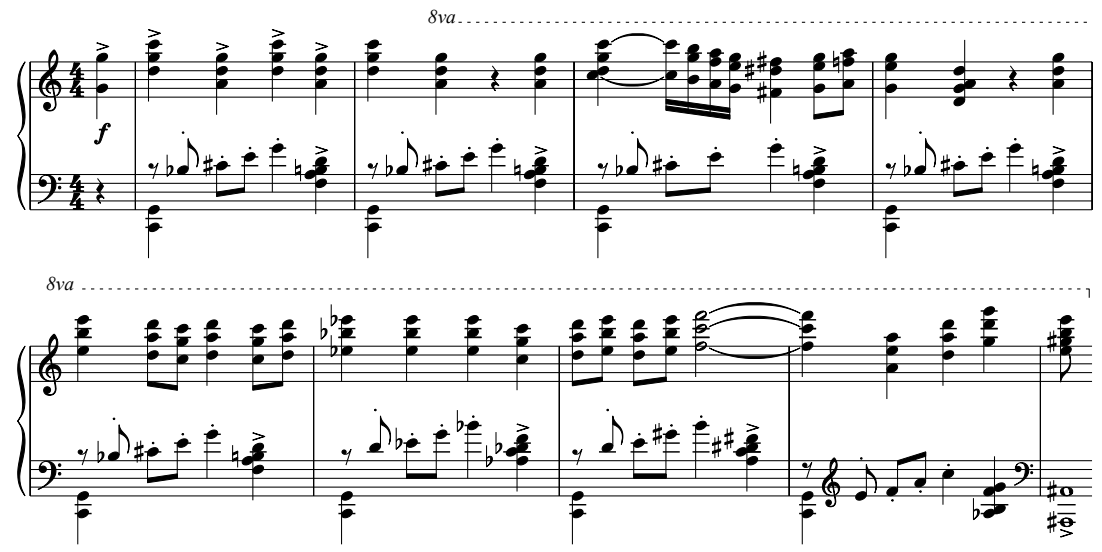

17c. Finale secondary theme (a textless Broadway ballad?), rehearsal 49
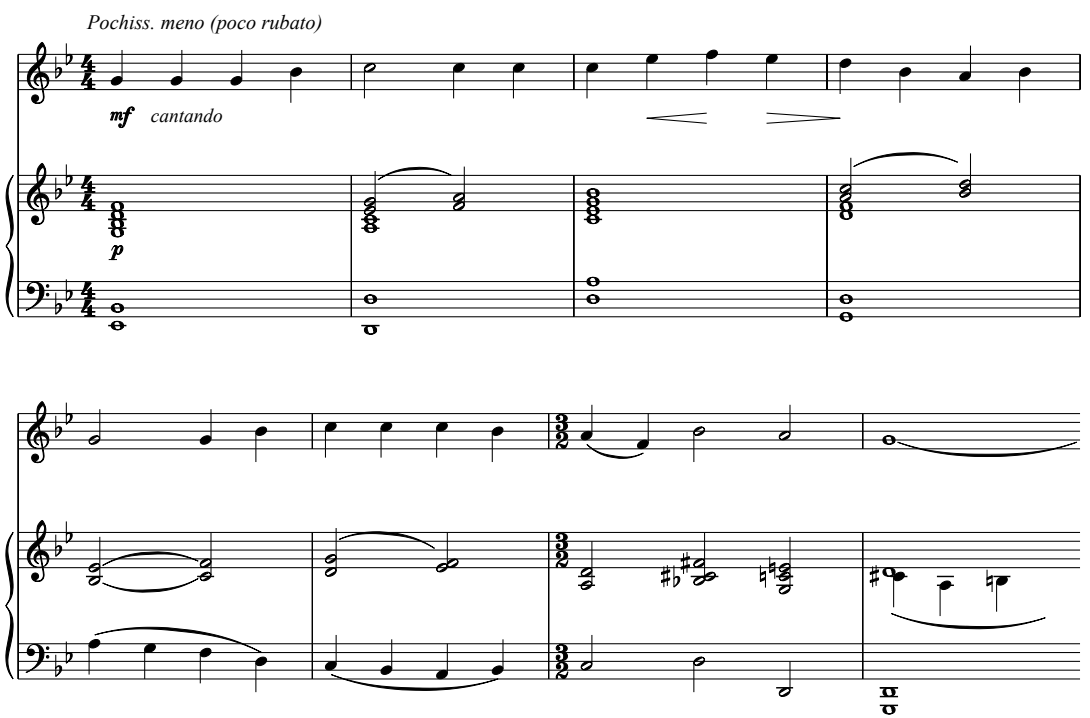
to the type of thematic development upon which larger formal structures depend. The first movement of the Cello Concerto, marked Maestoso, makes no show of attempting a sonata form. It is instead episodic in construction, serving as an introduction to the larger work. To extend the movement's length, Duke simply varies his themes with each appear-ance. In a lyrical compositional language like Duke's, accompanimental variation and thematic extension serve a greater expressive purpose than does traditional development of motivic fragments. The slow move-ment, labeled an "aria," concerns itself with a continuous spinning-out of two principal ideas in the cello's long-breathed lines. It is the finale, marked Allegro brioso, which most closely resembles a sonata form. Con-trasting primary and secondary themes are in place, with the requisite harmonic motion from $\mathrm{C}$ major to $\mathrm{G}$ major/ minor, but the subsequent "development" section presents each theme intact, separately, and in varied settings. The eventual return of the primary theme arrives like a traditional recapitulation in a full orchestral tutti, but Duke again deploys his themes in order and in varied presentations, each time restating his melodic ideas in full. Thus he essentially takes the listener through the same material three times. Duke concludes the concerto with a presto coda built upon yet another variation of the march-like primary theme. While his structure is not very convincing as a sonata form, it is his use of variation technique and the inherent high quality of his themes that hold this episodic movement together. ${ }^{38}$ Irving Fine seemed to suggest as much when he reviewed the work for Modern Music. He described the concerto as "a brilliantly written piece with promising thematic material, a solid first movement, a romantic second and a finale of infectious gay-ety . . . yet all these fine things failed to fuse into a unified impression." 39 If Duke struggled to successfully solve the problem of large-scale form, his melodic gift and harmonic inventiveness were exactly what both the smaller classical forms and the American popular song demand.

$* * *$

By focusing on compositions from within a narrow time frame as I have done here, I obviously skirt the issue of stylistic evolution. I can offer only a brief overview here. While Duke's style as a popular songwriter remains consistent throughout four decades, Dukelsky's classical style did not. Consider his earliest success, Zéphyr et Flore (1925). It presents a rather derivative stylistic language, at different times reminiscent of Prokofiev, Stravinsky and Les Six, and not at all like the mature Dukel-sky (or Duke) of the 1940s. ${ }^{40}$ Only in the primary melody of the central theme and variations that make up the ballet's "Divertissements des Muses" is there evidence of the memorable melodic voice that would make Duke's popular songs such a success. Yet even this tune would likely be identified as echt-Prokofiev by most listeners. ${ }^{41}$ There is, how- 
ever, an undeniable freshness to the score; this is young man's music inspired by the composer's first major break. Duke was clearly stimulated by his encounter with the vibrant Parisian artistic scene. Even though he was beginning to dabble in popular-song work, with this composition he was embarking upon his intended career path.

Sergei Prokofiev, who had first met Dukelsky the previous fall and would later become the composer's closest musical friend after Gersh-win, was particularly impressed with the new ballet score. ${ }^{42}$ After its pre-miere he remarked to Boris Asafiev that of "the new pieces I've heard this spring," this score was "the most interesting one." 43 Writing to Nikolai Miaskovsky, he enthused that the "ballet is very well done, with a mass of very beautiful material" and concluded the letter by notating the first eight measures of the theme-and-variations' melody as if to illustrate and support his opinion. ${ }^{44}$ Prokofiev's enthusiasm for the work takes on added meaning when one realizes that, as David Nice explains, Dukel-sky was "the first composer whose music Prokofiev was aware showed his own influence." 45 Prokofiev would long remain a champion of the classical composer Dukelsky, and yet he would later take on a scolding tone of disappointment and disapproval as Duke began to devote more of his time and efforts to the popular sphere.

By the early 1930s, when Duke's first popular song hits were marking the beginning of this "second" composer's fame, his approach to classical composition grew more intellectually serious and insistently abstract. In a letter written just five years after his enthusiasm for the Zéphyr ballet, Prokofiev recognizes this shift and challenges his younger colleague:

No matter how you might pretend and prevaricate, the fact is that you like your half-respectable bread. . . . But if I were to ask you what you have accomplished in the last year in the field of real music, then aside from two rather dry piano pieces you couldn't show me a single thing. The dryness of these pieces very accurately reflects your present situation: when, after a long hiatus, you decide to take up "serious" music once again, you're very fearful to display some sign of the "operetta-ness" that has now become (even though you haven't noticed it) your very flesh and blood. ${ }^{46}$

The compositional tendency to avoid any suggestion of popular music by resorting to a "dry" modernist style is apparent in the 1931 Epitaph for soprano, chorus and orchestra, a work composed in memory of Di-aghilev. ${ }^{47}$ This work lacks the rhythmic vitality and melodic charm of the earlier ballet and instead comes off as a rather dour exercise in "anti-popular" music. It was not a success at its Boston Symphony premiere, and even Duke himself would express his displeasure with the "drier and more cerebral" nature of his classical works from this period. He rather unforgivingly described the Epitaph as "a diffuse, delicate piece 
with some lyrical high spots . . . but the orchestration was muddy and colorless." 48 For his part, Prokofiev at first could not even bring himself to examine the score, as he was "overcome by a feeling of disgust" when he realized that it had been "written on jazz paper" instead of a more classically appropriate type of staff paper. Again writing to Miaskovsky, he worried that Duke's "inspiration has somehow just completely dried up." 49 By affecting this more severe compositional style, even though it quickly proved to be an ineffective and uninspired one, Duke self-consciously sought to confirm his continued validity as a composer of serious art music. At this stage in his career, he seemed anxious to prove that his popular successes did not diminish his stature as a legitimate modern composer.

The late 1930s and the 1940s can be seen as a period of consolidation as Duke-Dukelsky's mature compositional style takes shape. As we have seen above, overlapping style features emerge that link the composer's dual spheres of activity. By the 1950s, this process of consolidation was complete. Duke-Dukelsky finally seems comfortable in his own compo-sitional skin, happily embracing the broad spectrum of artistic outlets available to a composer of both popular songs and concert music. His Broadway successes no longer seem to haunt his classical half. The String Quartet in C (1956), for instance, offers an approachable yet modern clas-sical style. ${ }^{50}$ The fourmovement work is lyrical throughout, formally clear, and far removed from the abstract style of the Epitaph. Duke's sound world is certainly not derivative of other classical composers here, and yet the quartet never sounds anything like a Broadway show tune either. The opening movement's tempo indication, Affabile, is in fact an apt de-scription of the quartet's overall outgoing character. Nor does the work outstay its welcome, lasting a mere sixteen minutes. The quartet was composed after Duke had stopped using "Vladimir Dukelsky" to sign his classical compositions. No longer is the composer trying to prove his art-music credentials to the establishment; instead he is simply compos-ing high-quality music. No longer are Duke and Dukelsky competitors; instead he is simply Vernon Duke, American composer.

But if so, why did he feel compelled to describe himself as "two composers rolled inexplicably into one"? Why did he insist on segregating what he called "my two kinds of music"? In part, the "Duke-Dukelsky partnership," to use his own epithet, is a response to the opinion held by friends and critics alike that his stylistic versatility was a liability rather than an asset. In his early London days, Duke discovered "that ballet composers, while perfectly acceptable in their frivolous sphere, were not easily transplantable into the loftier symphonic regions of England. Bal-let was bad enough in the eyes of the saturnine satraps who ruled that country's musical opinion, but all that 'Vernon Duke' nonsense was really inexcusable." Likewise, the Tin Pan Alley publisher Max Dreyfus warned 
him 'with great deliberation that 'serious' and 'light' music didn't mix, that being successful in one field excluded the chance of success in the other, that there was no future in that sort of thing." 51 Prokofiev was especially critical of the time Duke spent writing for Broadway shows and always encouraged him to get back to composing classical music. In one letter, he contemptuously referred to Duke's "perpetual pandering to the scum of New York music." 52 He even went so far as to categorize Duke's output as either "music" for classical compositions or "tra-la-la" for the popular songs. ${ }^{53}$ After reading one particularly harassing letter from Prokofiev, Duke "rushed to the writing table to prove to myself that I was still Dukelsky, composer, not Duke, tunesmith." 54

With his two separate identities, Duke could find the strength to face such criticism. The composer created a façade whereby one man, Ver-non Duke, composed Broadway musicals that are not complicated by the highbrow modernism of a classical composer. Meanwhile, Vladimir Dukelsky was free to compose symphonies and concertos without the at-tached stigma of being a lowbrow Broadway songwriter. Thus Dukelsky could continue down the path begun with Glière at the Kiev Conserva-tory as an ambitious composer of art music, while Duke could pursue a more commercially viable course writing popular songs.

This distinctive division eventually became the defining feature of his mature American career. Duke writes: "[T]here was no denying that my dichotomy, unnatural and irritating (because nonclassifiable) to my contemporaries, had now become an all-enveloping characteristic of my musical self-expression; in other words, it seemed impossible for me to stick to one kind of music, without an occasional welcome excursion into the other field." Duke was able to leverage this constant zig-zagging between concert works and popular songs into a creative benefit. A financial success with one type of music could help to fund a composi-tion in the alternate sphere. Following his triumphs on Broadway and in Hollywood during the 1930s, Duke "hit on the idea of letting the fairly solvent Duke pay for Dukelsky, the pauper." Alternately, when faced with failure on one front, he could turn to the other for a "welcome excursion" into different scenery, so to speak. For instance, during the late 1940s, after "six or seven [Broadway] flops in a row," Duke "could thank my stars for having created a two-headed monster-with a two-track music mind" because his classical compositions continued to be artistically successful. At other times, Duke found that his "destitute alter ego, Dukelsky, came in mighty handy" when he grew "sick of [his] theatrical ups and downs." There even arose a friendly rivalry between the two composing halves. After a particularly successful period in early 1930 along the classical front, "Duke, jealous of Dukelsky's progress, began functioning at last" by signing a contract to write songs for Para-mount Pictures. Later, while in Belgium for the premiere of his Third 
Symphony in 1947, Duke "was flattered when one of the first violinists produced a copy of my Violin Concerto and asked me to inscribe it. People often ask Duke to autograph his songs or records; they seldom bother Dukelsky with such requests." 55

Composing under the dual mantel of either Duke or Dukelsky offered him an escape from problematic projects and the flexibility to prevent creative fatigue. One specific example serves to illustrate the benefits of this flexibility. While working on a cantata called The End of St. Petersburg in his most "advanced" 1930s concert style, Duke was called away to help persuade the director John Murray Anderson to revamp the fail-ing Ziegfeld Follies of $1934 .{ }^{56}$ Duke writes, "It's a far cry from Peter the Great's folly to the Follies of Ziegfeld, but my life was full of such abrupt transitions and I gradually became so used to them that proceeding in a straight line to a well-defined goal would have been a hindrance rather than a blessing." 57 The St. Petersburg cantata project itself arose follow-ing a temporary falling-out with Yip Harburg, lyricist of Duke's songs in the Follies. In this situation, the "Duke-Dukelsky partnership" acted as both an artistic escape and a creative stimulant.

The composer himself identified two Duke-Dukelsky "collaborations" in his output. For Vincente Minnelli's 1936 revue The Show Is On, he composed "a curious bit of Americana named the 'Tradegian' (subtitled 'The Ballet of the Barnstormers'), the music of which, in view of its com-plexity and comparative daring, was signed Vladimir Dukelsky." 58 The following year, he scored a "Romeo and Juliet" ballet sequence devised by Balanchine for the film Goldwyn Follies. In order to differentiate be-tween the two families, the composer explains that "quite logically, I wrote Duke music for Romeo, Dukelsky music for Juliet." 59 In both cases, "Duke" and "Dukelsky" are nothing more than convenient labels for the opposite ends of the composer's style spectrum. "Duke" designates jazz harmonies, swing rhythms, and dance-band scoring while "Dukelsky" connotes heightened melodic and harmonic complexity, greater disso-nance, and symphonic scoring.

Admittedly, some writers felt that Duke's dual activities weakened the effectiveness of his music. One critic complained in 1945 that "Vladimir Dukelsky's Second Symphony [an early work, dating from 1928-30] . . . shows what convincing music this composer wrote before he became involved with Broadway." 60 This is precisely the kind of criticism that he had hoped to avoid through the construct of his split identity. But other critics were less concerned, as these comments pertaining to a work for piano and orchestra called Dédicaces reveal: "The music has occupied Dukelsky since 1934 and, despite the frequent appearances of Vernon Duke in its pages, represents a great advance in technique." ${ }^{\prime \prime 1}$ Alec Wilder even found such mixing to be a positive trait. In discussing "Autumn in New York" he writes: "The verse may be the most ambitious I've ever 
seen. It begins simply enough, but halfway through it's almost as if the other musical half of the man couldn't be silent and the rest of the verse was finished by Dukelsky. It's extremely difficult and very lush. But I find it very interesting, and I approve of its experimental nature." 62

What then are we to make of Duke's claim that "there isn't a note of jazz in my serious music, and there are no symphonic overtones to my musicalcomedy output"? ${ }^{63}$ This claim makes the most sense when considered against the context of a work like Gershwin's Rhapsody in Blue. Here, Gershwin's musical language is infused with the rhythms, harmonies, melodic shapes, and blue notes of "jazz." In the concert works of Dukelsky, on the other hand, the composer does not seek to blend jazz materials into a classical setting. The pervasive syncopations and cakewalk rhythms in the primary melody of the second Caprice are surface-level rhythmic features and do not represent an intentional mimicking of or borrowing from the jazz style. A middle-of-the-spec-trum piano piece like the "New York Nocturne," which does display jazz traits, is signed by Vernon Duke and not Dukelsky. Thus, the first half of Duke's statement is partially an attempt to vouch for the "pu-rity" of his classical style. On the flip side, by disavowing "symphonic overtones" Duke seeks to reassure a Broadway public suspicious of highbrow composition. To stress this distinction-as Duke, Carter, and Wilder have-belies the musical threads that run consistently through-out the composer's output. Tracing this stylistic consistency reveals a unity that previous writers, including Duke himself, have either over-looked or intentionally downplayed.

On March 7, 1939, Vladimir Dukelsky became an official citizen of the United States of America and legally changed his name to Vernon Duke, although he continued to sign his classical works as Dukelsky. Finally even this pretense was abandoned, as Duke announced in the final paragraph of his autobiography: "I'm dropping the name of Vladi-mir Dukelsky and henceforth will sign all music that may still flow from my pen-regardless of its nature - as Vernon Duke." 64 In book reviews of Passport to Paris, writers had a field day with this sudden reversal. ${ }^{65}$ Claudia Cassidy comments that "the book is Vernon Duke's farewell to a man he has supported for decades, Vladimir Dukelsky, the original but now discarded half of the one man team known by the Russian name in 'serious' music, and by the acquired one to Broadway and Hollywood." 66 John Watson, tongue-incheek, writes that "Vernon Duke and Vladimir Dukelsky lived together amiably for years. ... When we saw Duke recently he was plotting to murder Dukelsky. As this ap-pears the foul deed has been done." ${ }^{67}$ By the 1950s, Duke recognized that "Times have changed. Versatile Lennie Bernstein writes the Jeremiah Symphony with one hand, Wonderful Town with the other-and no one gives a hoot." 68 During the 1930s and 1940s, the road to success was 
easier if Duke accepted the established cultural hierarchy and presented his two sides as separately named individuals. Times had changed; the need for separate, independent identities became a moot point.

From the earliest stages of his career, Duke was involved in musical activities - both classical and popular - that most Americans understood to be separate pursuits, so it comes as no surprise that he should have continued his involvement in both realms throughout his lifetime. By discovering the musical features that link his output across the whole stylistic gamut, we are able to reunite this composer's two halves. Duke's stylistic diversity can now be seen as the musical expression of his own open-minded artistic credo:

I refused to take sides and listened avidly to the music around me, hoping for new sounds and new directions and disregarding the source whence they came. It's no idle boast when I say that I never let personalities or musical politics interfere with my appraisal of music, nor when I claim to be able to listen to a new work with-out checking with the program to make sure that it is musically "respectable" or having my enjoyment colored by the presence or lack of such respectability. ... [I]n short, I liked — and still like — all living music, the spontaneous utterance of every talented musician, every fresh, "reachable," non-sterile, noncalculated, unprefaced, unapologized-for musical realization. ${ }^{69}$

Duke here tells us how we ourselves should approach his music to-daynot by worrying about whether it was composed by the "respect-able" Dukelsky versus the "non-sterile" Duke, but by "disregarding the source." By operating so fluently and successfully in both the classical and popular spheres, Duke proved himself to be a true practitioner of "living music."

\section{NOTES}

Special thanks to my anonymous readers whose suggestions helped to expand the breadth and clarity of my analysis here, and to Jeffrey Magee whose advice helped to shape the earliest stages of this project. An abbreviated version of this paper was first read at the annual meeting of the American Musicological Society in Nashville, November 7, 2008.

1. In fact, the cover is that of the two-piano version of George Gershwin's Piano Concerto in $F$. Perhaps, given the staged nature of the photo, the inclusion of this score is something of an homage to George, who had died shortly before this photo was taken.

2. Vernon Duke, Passport to Paris (Boston: Little, Brown, 1955). Duke occasionally misremembers dates or presents minor chronological inaccuracies, in addition to falling into a tendency to overemphasize his own role in some of the anecdotes he relates. However, his writing is notably forthright and honest when it comes to expressing his understanding of his own career and music. It is upon this material that much of my treatment will draw.

Duke also authored Listen Here!: A Critical Essay on Musical Depreciation (New York: Ivan 
Obolensky, 1963). In this later book, he writes perceptively and insightfully on the state of the American musical scene, circa 1960, but is hesitant to discuss his own music, except when he is complaining about how few performances his works receive. This is partly a reflection of his diminishing compositional output toward the end of his life.

3. Duke, Passport to Paris, 3. The use of the term jazz is perhaps problematic in this context. Duke too struggled with this in his autobiography: "I became an 'early-jazz' fiend. That's not quite what I mean, because (shudder, ye New Orleans purists!) the 'real' New Orleans jazz and the true blue blues impressed me considerably less. 'What can you expect from a long hair' did I hear you say?" (77). Duke uses the term jazz in the same sense that the songs of George Gershwin or Irving Berlin are "jazz."

4. "Vernon Duke, Composer, Dead; Wrote the Hit Cabin in the Sky," New York Times, Jan. $18,1968$.

5. Duke, Passport to Paris, 303.

6. Elliott Carter, "Orchestras and Audiences: Winter, 1938," Modern Music 15 (1938): 170.

7. Throughout the autobiography, Duke uses the term serious music to refer to his art music compositions. I will also employ the term classical music in its most general, generic sense to refer to his works for concert or recital performance. This is in distinction to popu-lar songs, which are composed for use in Broadway musical theater or Hollywood film musicals. Duke was equally "serious" whether writing for Carnegie Hall or a Broadway stage.

8. Alec Wilder, American Popular Song: The Great Innovators, 1900-1950 (New York: Oxford University Press, 1972), 357.

9. Aaron Copland, "Contemporaries at Oxford, 1931," Modern Music 9 (1931): 19. Admittedly, Copland's comments predate any of Duke's truly successful popular songs, but Duke had been composing popular songs for musicals for several years already, so there is no reason why Copland must ignore this portion of his output.

10. Duke, Passport to Paris, 6.

11. Ibid., 62, 79 .

12. Ibid., 88,95 .

13. Ibid., 92 .

14. Duke completed this concerto in December 1923. Although Rubinstein was impressed with the work, no performance ever materialized. During Duke's lifetime, he only published a two-piano score and left the work unorchestrated. The work had to wait until 1999 before it was finally premiered at Carnegie Hall. Scott Dunn, the soloist on this occasion, supplied the orchestration and has recorded the work on the Naxos Ameri-can Classics label (8.559286). Also see Anthony Tommasini, "With a Debt to Fascinating Rhythm," New York Times, Jan. 12, 1999.

15. Duke, Passport to Paris, 103-4.

16. More than any of Duke's earlier classical efforts composed during his first U.S. period, this work brought him to the attention of the American contemporary music scene. See Nicolas Slonimsky, "Vladimir Dukelsky," Modern Music 4 (1927): 37-8.

17. Duke, Passport to Paris, 177, 218.

18. Ibid., 176-77.

19. Ibid., 368.

20. The Broadway version of Cabin in the Sky (with a book by Lynn Root, lyrics by John Latouche, choreography by George Balanchine, and an all-black cast) opened in October 1940 and ran for 156 performances. The MGM movie version, directed by Vincente Min-nelli, was released in 1943 with additional songs by the Arlen-Harburg team.

Despite the score's popularity and genuine hit status of several of the songs, Alec Wilder holds a negative opinion: "At no point is there any aspect of Duke's invention and musical-ity. I don't even consider ['Taking a Chance on Love'] a theater song. The title song ['Cabin in the Sky'] is better . . . but again it has none of what one looks for in Duke's music. It's 
competent and professional, but that's about it. . . [ ['Honey in the Honeycomb'] continues to sound like an assignment" (Wilder, American Popular Song, 366). Wilder is dissatisfied because he considers these songs to be less sophisticated than Duke at his best. The dis-tinctive markers of the Duke style are notably absent from "Taking a Chance on Love," although they do appear in the other two tunes Wilder dismisses, hence their inclusion in my own study. For Duke's discussion of Cabin in the Sky, see Passport to Paris, 382-94.

21. The Victorian Songs were dedicated to the memory of Duke's mother, who had re-cently passed away. See Passport to Paris, 407-8.

22. Rudolf Reti, Tonality - Atonality — Pantonality: A Study of Some Trends in Twentieth Century Music (London: Rockliff, 1958), 67 and 21.

23. Elie Siegmeister, Harmony and Melody, vol. 2, Modulation; Chromatic and Modern Styles (Belmont, Calif:: Wadsworth Publishing, 1966), 353.

Here and in subsequent sections of this article, I am interested to examine how certain compositional style traits, particular to if not unique to Duke, were seen through the eyes of his contemporaries. Although my selection of writers like Rudolph Reti (1885-1957), Elie Siegmeister (1909-91), and later Marion Bauer (1882-1955) may seem dated today, they all supply "first-hand reporting" on how Duke's then-contemporary compositional devices were perceived and understood. Note that all three were composers as well as writers and theorists.

24. Bauer attributes the fad for parallelism to Debussy, noting that "[i]t must not be believed that Debussy was the first to use consecutive chord sequence, but he was the first to make it a mannerism." Marion Bauer, Twentieth Century Music: How It Developed, How to Listen to It (New York: G. P. Putnam's Sons, 1933), 143.

25. Sadie Thomson, the show from which this song comes, was a flop, but Duke is quick to point out the song's eventual financial success. See Passport to Paris, 428.

26. The bass pitches of his chords still retain their traditional harmonic function; even if a chord is a triad, Duke will often voice it as two stacked fifths: 1 and 5 in the bass, 3 and 7 in the treble - a voicing that was then becoming a standard in jazz.

27. Vernon Duke, Parisian Suite (New York: Broude Bros., 1956).

28. The "New York Nocturne" is one of "a geographical series [of piano pieces] glorifying

American cities." Duke considered this to be "the best of them" (Passport to Paris, 382).

29. Stephen Holden, “Artfully Confiding a Songwriter's Art,” New York Times, Jan. 25, 1999.

For another similar viewpoint see Rebecca Paller, review of the compact disc Dawn Upshaw Sings Vernon Duke, Opera News 63, no. 10 (April 1999): 81-82.

30. Siegmeister's remaining items are "varied scale patterns" and "intricate rhythmic structure." Siegmeister, Harmony and Melody, 368.

31. Using "extreme" as a descriptor of the ranges of Duke's popular song melodies is perhaps stretching the point, but the tessitura of his songs is generally wider than the Tin Pan Alley average.

32. Bauer, Twentieth Century Music, 128.

33. Wilder, American Popular Song, 368.

34. Allen Forte, The American Popular Ballad of the Golden Era, 1924-1950 (Princeton, N.J.: Princeton University Press, 1995), 334.

35. 29 Modern Piano Interpretations of Stephen C. Foster's "Swanee River" (Old Folks at Home) by America's Foremost Modern Composers, Pianists and Arrangers (New York: Robbins Music, 1939).

36. Note that these names all come from the popular and jazz side of the spectrum; classical composers are not among the participants. Grofé and Still appear here in their capacity as jazzband arrangers rather than concert-music composers. Thus Vernon Duke, and not Vladimir Dukelsky, contributed a variation.

37. This concerto was recorded by cellist Sam Magill on the same Naxos CD mentioned in n. 14 above.

38. Olin Downes, after hearing Piatigorsky and Koussevitzky present the New York 
premiere, described the concerto as a "difficult and brilliantly sounding work" and praised its "inherent vitality and interest," even if he was worried that Duke's "arsenal of 'modern' effects" were "sometimes artificial, and even as of today, old fashioned. The tricks were fresh a couple of decades ago, but they quickly stale and weaken what is genuine in the music." His negativity toward Duke's "stale" modernism appears overly critical to this listener. Olin Downes, "Boston Symphony Offers New Work," New York Times, Jan. 10, 1946.

39. Irving Fine, "Symphonic Works and Fauré Anniversary," Modern Music 23 (1946): 56.

40. A recording of the complete ballet score conducted by Gennady Rozhdestvensky is available from Chandos (CHAN 9766).

41. We have already encountered the Prokofiev-Dukelsky comparison in Aaron Cop-land's 1931 style assessment quoted near the beginning of this article. As early as 1927, Slonimsky recognized that "a spiritual kinship with Prokofiev can often be discerned" (Slonimsky, "Vladimir Dukelsky," 38).

42. Duke names them "my two best friends in music: George Gershwin, Duke's creator, and Serge Prokofiev, Dukelsky's protector" (Passport to Paris, 367).

43. Letter from Prokofiev to Boris Asafiev, June 24, 1925, in Selected Letters of Sergei

Prokofiev, ed. Harlow Robinson (Boston: Northeastern University Press, 1998), 101.

44. Letter from Prokofiev to Miaskovsky, Aug. 4, 1925, in ibid., 259.

45. David Nice, Prokofiev: From Russia to the West, 1891-1935 (New Haven: Yale University Press, 2003), 209.

46. Letter from Prokofiev to Duke, Nov. 9, 1930, in Selected Letters of Sergei Prokofiev, ed. Robinson, 145-46.

47. The piece is coupled with Rozdestvinsky's recording of Zéphyr et Flore.

48. Duke, Passport to Paris, 246, 257.

49. Letter from Prokofiev to Duke, June 3, 1932, and letter from Prokofiev to Miaskovsky, May 22, 1931, both in Selected Letters of Sergei Prokofiev, ed. Robinson, 148; 292.

50. This work was recorded by the Roth Quartet and released on a late-1950s LP on the Contemporary Records label. Duke also appears as pianist on this album performing his own Surrealist Suite and the Three Caprices discussed in this article. None of these record-ings have ever been made available on CD.

51. Duke, Passport to Paris, 211, 255, 261, 269, 298.

52. Letter from Prokofiev to Duke, June 3, 1932, in Selected Letters of Sergei Prokofiev, ed. Robinson, 148.

53. Prokofiev wrote: "What have you composed 1) in the way of music, 2) in the way of trala-la? Is the tra-la-la still paying well?" Letter from Prokofiev to Duke, April 5, 1940, in ibid., 158 .

54. Duke, Passport to Paris, 291.

55. Ibid., 234-35, 292, 359, 396, 428, 453.

56. Since Anderson considered Duke's three songs to be the only salvageable parts of the show, Duke was enlisted to help convince the director to step in and take over the project. In its reconstructed version under Anderson's leadership, the Follies ran for 182 performances and ultimately featured five songs by Duke. For Duke's full telling of this episode, see ibid., 289-90.

57. Ibid., 289.

58. Ibid., 337. This ballet was eventually cut from the revue.

59. Ibid., 358. Unfortunately, the finished cut of the film drastically reduced the length of Duke's music for this ballet sequence, thus obscuring the impact of the stylistic dichotomy between the "Duke music" and the "Dukelsky music."

60. Donald Fuller, "Russian and American Season, 1945," Modern Music 22 (1945): 255

61. George Henry Lovett Smith, "Boston News," Modern Music 16 (1939): 116. 
62. Wilder, American Popular Song, 361.

63. Duke, Passport to Paris, 3.

64. Ibid., 484.

65. At least it was perceived as sudden at the time. As my overview of Dukelsky's evolving classical style might suggest, the composer had indeed been heading in the direction of needing only one personal identity for quite some time.

66. Claudia Cassidy, "A Farewell to His Other One Half," Chicago Daily Tribune, April 17, 1955.

67. John Watson, "A Clear Case of Murder," article in a scrapbook in the Vernon Duke Collection (Box 144), Library of Congress, attributed in pencil to the New York Journal American, 1955. Special thanks to Jeff Magee for accessing this source.

68. Duke, Passport to Paris, 254.

69. Ibid., 253. 